\title{
Anaerobic Fermentation Effectively Reduces Concentration of Total Tannins in Chromolaena odorata
}

\author{
Mullik YM ${ }^{1,2}$, Ridla $\mathrm{M}^{1}$, Prihantoro ${ }^{1}$, Mullik $\mathrm{ML}^{2}$ \\ ${ }^{1}$ Faculty of Animal Science, Graduate School, Bogor Agricultural University, Indonesia \\ ${ }^{2}$ Faculty of Animal Science, University of Nusa Cendana, Indonesia \\ E-mail:martin_kpg@yahoo.com.au
}

(received 22-01-2016; revised 24-03-2016; accepted 29-03-2016)

\begin{abstract}
ABSTRAK
Mullik YM, Ridla M, Prihantoro I, Mullik ML. 2016. Fermentasi anaerobik efektif menurunkan konsentrasi total tanin pada tumbuhan semak bunga putih (Chromolaena odorata). JITV 21(1): 19-25. DOI: http://dx.doi.org/10.14334/jitv.v21i1.1301

Chromolaena odorata merupakan sumber pakan alternatif potensial, namum penggunaannya terkendala oleh kandungan berbagai senyawa metabolik sekunder dalam jaringan tumbuhan ini. Salah satu kelompok senyawa tersebut adalah tannin. Penelitian ini bertujuan untuk mengevaluasi pengaruh berbagai metode perlakuan awal terhadap total konsentrasi tannin dan daya cerna bahan kering dan bahan organik yang diukur secara in vitro dan konsentrasi produk fermentasi rumen. Rancangan acak lengkap $(8 \times 3)$ digunakan untuk menguji perbedaan 8 jenis perlakuan yaitu daun chromolaena segar sebagai kontrol (Fresh), dijemur selama $3 \times 24$ jam (Sun-dried), dikeringkan pada suhu $60^{\circ} \mathrm{C}$ selama 24 jam (Oven-dried), direbus dalam air selama 5 menit (Boiled), direndam dalam air biasa selama 4 jam (RenWater), direndam dalam $\mathrm{NaOH}$ selama 4 jam $(\mathrm{RenNaOH})$, direndam dalam $\mathrm{HCl}$ selam 4 jam (RenHCl), atau difermentasi secara anaerobik selama 21 hari (Fermented). Parameter yang diukur adalah konsentrasi tannin total dan kandungan nutrisi dalam setiap bahan yang mendapat perlakuan tertentu. Hasil penelitian menunjukkan bahwa perlakukan Jemur, Rebus, RenAir, dan fermentasi secara nyata menurunkan total tannin sehingga besar $43 \%$ hingga $62 \%$ dibandimg kontrol. Penurunan terbesar (62\%) ditunjukkan oleh perlakukan Fermentasi. Sebaliknya, penggunaan panas tinggi (dioven) atau bahan kimia ( $\mathrm{HCL}$ dan $\mathrm{NaOH}$ ) tidak nyata menurunkan konsentrasi tannin. Kandungan protein kasar meningkat sebesar $60 \%$ dan serat kasar menurun sebesar $32 \%$ pada perlakuan fermentasi dibanding kontrol. Disimpulkan bahwa metode fermentasi anaerobic dapat digunakan sebagai strategi efektif untuk menurunkan konsentrasi tannin dalam tumbuhan semak bunga putih (Chromolaena odorata) tanpa mengurangi nilai nutrisinya sebagai bahan pakan.
\end{abstract}

Kata Kunci: Chromolaena odorata, Tannin, Daya Cerna, $\mathrm{NH}_{3}$, VFA

\begin{abstract}
Mullik YM, Ridla M, Prihantoro I, Mullik ML. 2016. Anaerobic fermentation effectively reduces concentration of total tannins in Chromolaena odorata. JITV 21(1): 19-25. DOI: http://dx.doi.org/10.14334/jitv.v21i1.1301

Chromolaena odorata is a potential feed source but its usage is hampered by presence of various secondary metabolic compounds in plant's tissues. One group of them is tannin. This experiment was aimed to evaluate various pre-treatment methods on total tannin concentration and in vitro digestibility of dry- and organic-matter. An $8 \times 3$ completely randomized experimental design was employed to test 8 different treatments. The treatments were: Fresh $=$ freshly-chopped chromolaena leaves as control, Sun-dried $=$ sun-dried $\left(3 \times 24\right.$ hours) chromolaena leaves, Oven-dried $=$ oven-dried $\left(60^{\circ} \mathrm{C}\right.$ for 24 hours) chromolaena leaves, Boiled $=$ water-boiled $(5$ minutes $)$ chromolaena leaves, RenWater $=$ water-soaked $(4$ hours $)$ chromolaena leaves, $\mathrm{RenNaOH}=\mathrm{NaOH}$-soaked (4 hours) chromolaena leaves, $\mathrm{RenHCl}=\mathrm{HCl}$-soaked $(4$ hours) chromolaena leaves, and Fermented $=$ anaerobically-fermented $(21$ days $)$ chromolaena leaves. Parameters measured were concentration of total tannins and nutrient content. The results showed that application of low heat (Sun-dried), hot water (Boiled), water soaking (RenWater), or unaeobic fermentation technique significantly reduced total tannin by $43 \%$ into $62 \%$ compared to control. The highest suppression (62\%) was achieved by Fermented treatment. In the contrary, medium heat application (oven-dried at $60^{\circ} \mathrm{C}$ ) or chemicaltreatments $(\mathrm{HCl}$ or $\mathrm{NaOH})$ had no effect. Protein content of chromolaena was improved by $60 \%$ and crude fiber was reduced by $32 \%$ in Fermentaed treatment compared to the control. It could be concluded that anaerobic fermentation can be used an effective strategy to reduce tannin concentration in Chromolaena odorata without affecting its feeding value.
\end{abstract}

Key Words: Chromolaena odorata, Tannins, Digestibility, $\mathrm{NH}_{3}$, VFA

\section{INTRODUCTION}

Siam weed (Chromolaena odorata) is a pasture weed for Eastern Indonesia rangelands which have extremely high biomass production (up to 70 ton
$\mathrm{DM} / \mathrm{ha} /$ year) with crude protein content of about 21$36 \%$ (Mullik 2002) yet contains various anti-nutrient agents in the form of secondary methabolic compounds. Some of these secondary methabolic properties are tannins, anti-trypsine, haemaglutinnine, saponine, 
oxalate, pitate acid, alkaloids, steroids, terpoids, and flavonoids (Akinmoladun et al. 2010; Onkaramurthy et al. 2013). The presence of these compounds lower palatability index of $C$. odorata (Hai et al. 2012) due to strong mint odour and relatively bitter taste. Ruminants rarely consume $C$. odorata in a fresh form. Therefore, pre-treatment is required to overcome these nutritional and intake limitations. The pre-treatments should be directed to reduce or eliminate anti-nutrient compouds but maintain nutrient quality and safe for animals and environment.

Tannin goup is a dominant anti-nutrient compound in $C$. odorata (Onkaramurthy et al. 2013). Reducing or eliminating tannins is likely to increase palatability and feeding value of this plant. Provision of feedstuff with high tannin content as single diet to livestock could surpress feed intake, palatability, daily weight gain (Wina 2010), protein degradation in rumen due to tannin-protein binding effects (Patra \& Saxena 2011), and toxic for rumen microbes (Bhatta et al. 2009). Tannins also have the potency to disrupt digestive tract function (Makkar 2003) due to an inhibition in the activities of digestive enzymes such as proteases, lipases, and glicocidases (Hagerman 1992).

Physical, chemical and biological treatments are existing pre-treatment methods used to reduce or eliminate tannins in feedstuff (Roger et al. 2015). Physical treatments (chopping, milling, pelleting), chemical treatments (heating, soaking in water or acid or alkali solution), and biological treatment (microbial fermentation) have been adopted worldwide in feed processing. Thus, they could be used to treat $C$. odorata to reduce its anti-nutrient properties. However, various researchers have shown that response of tannins to treatment is not consistant among feed sources. As an example, Hue et al. (2010) reported that withering and drying significantly reduce tannin concentration in cassava leaves, yet Wina et al. (2000) found an incrase in tannins in aerobically-dried Calliandra calothyrsus leaves. This inconsistency could be related to high variability in chemical structures of tannins among plants and plant materials (Patra \& Saxena 2011; Gemede \& Hassen 2015).

Due to the inconsistency in tannin response to processing, it is not clear, what is the effective pretreatment method to reduce tannin concentration in $C$. odorata. Two latest studies (Mullik et al. 2014; Bira et al. 2015) showed that a serial pre-treatments (sundrying, milling, and pelleting) still not able to guarantee that $C$. odorata can be used as a safe feed source for cattle. These researchers (Mullik et al. 2014; Bira et al. 2015) found that total feed intake, digestibility and rumen fermentation begins to decrease as inclusion of chromolaena meal in the diet increased from $30 \%$ to $40 \%$. Based on these findings, the present study was designed to test effects of sun-drying, oven-drying, water-boiling, soaking in water or $\mathrm{HCl}$ and $\mathrm{NaOH}$ solution, and fermentation on total tannins and nutrient content of $C$. odorata.

\section{MATERIALS AND METHODS}

This study was carriedout in August-December 2014. Tannin evaluation and analysis of nutrition content of $C$. odorata was conducted at Animal Feed Technology Laboratory (ITP) of Faculty of Animal Science, Bogor Agricultural University. C. odorata leaves used in this study were obtained from Kupang, East Nusa Tenggara. The leaves were harvested by pruning the plants at a height of $\pm 50 \mathrm{~cm}$ from the ground. The leaves were then separated from the rod and assigned to the treatments.

This study used 8 treatmets which were arranged in a 8 x 3 Completely Randomized Design. The treatments were:

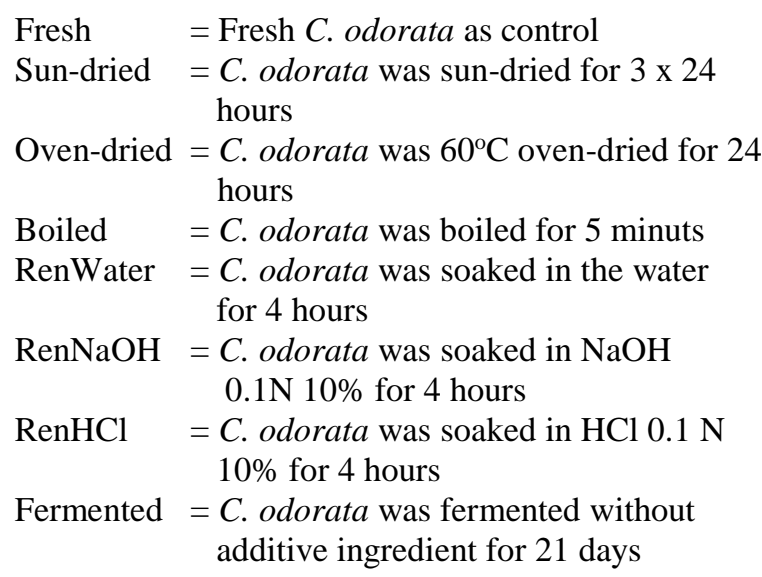

\section{Sampling and handling procedures}

For the first treatment (Fresh), C. odorata leaves were chopped as fine as possible and then used for analysis. For the sun-dried treatment, $C$. odorata leaves were spread on top of a tarp, dried under sun light for 3 days, finely grounded and then analyzed. For ovendried treatment, $C$. odorata leaves were placed in a tray and fed into oven at $60^{\circ} \mathrm{C}$ for 24 hours. Dried materials was then grounded, and analyzed. For boiled treatment, $C$. odorata leaves were boiled in water (with a ratio of $100 \mathrm{~g}$ leaves $/ 150 \mathrm{~mL}$ water) for 5 minutes using medium heat. The boiled materials was then filtered, wind-dried, finely chopped, and then analyzed for chemical composition. For the RenWater treatment, $C$. odorata leaves was soaked in plain water (a ratio of 200 $\mathrm{g}$ leaves/1000 mL water) at room temperature for 4 hours. For $\mathrm{RenNaOH}$ and $\mathrm{RenHCl}$ treatment procedures were same with the RenWater, but the solution used was $0.1 \mathrm{~N} \mathrm{NaOH}$ or $0.1 \mathrm{~N} \mathrm{HCl}$ (Ratio: $200 \mathrm{~g}$ leaves/1000 $\mathrm{mL}$ of $10 \% \mathrm{NaOH}$ or $10 \% \mathrm{HCl})$. After soaking, the 
samples were washed with fresh water to reduce negative effect of $\mathrm{NaOH}$ and $\mathrm{HCl}$, filtered, wind-dried, finely ground, and analiyzed. For fermentated treatment, fresh leaves were chopped, arranged into 1 litter jar, densified, air-tight sealed, and fermented for 21 days. After fermentation, the feedstuff was unpacked, wind-dried, then finely ground prior laboratory analyzes for chemical composition. All chemical analyzes were done at Animal Feed Technology Laboratory (ITP) of Faculty of Animal Science, Bogor Agricultural University.

\section{Parameters and measurements}

\section{Total tannins content}

Quantification of total tannins was done by analizing samples from each treatment. Sample (1.2 g) was extracted with aquades in $100 \mathrm{~mL}$ volumetric flask for 4 hours at room temperature, filtered using whatman paper number 40. About $10 \mathrm{~mL}$ supernatant was pippeted into $500 \mathrm{~mL}$ volumetric flask where $10 \mathrm{~mL}$ indigo carmine solution and $300 \mathrm{~mL}$ aquades were then added. This solution was then destilled using $0.1 \mathrm{~N}$ $\mathrm{KMnO}_{4}$ until the colour of the solution change from blue to green. The titration process continued until the colour of the solution turned into golden yellow. Standar solution of indigo carmine was made by dissolving $3 \mathrm{~g}$ of indigo carmine in $250 \mathrm{~mL}$ hot aquades and then cooled. After colling, $25 \mathrm{~mL} \mathrm{H}_{2} \mathrm{SO}_{4}$ was added and diluted into $500 \mathrm{~mL}$ aquades. The mixture was then allowed to cool down befored filtered. The blank standard was made of $10 \mathrm{~mL}$ indigo carmine solution and $300 \mathrm{~mL}$ aquades.

Total tannin concentration was obtained by using titrimetric method according to Atanassova \& Christova-Bagdassarian (2009) modified from The International Pharmacopoeia (2003) and AOAC (1965).

$$
\mathrm{T}(\%)=\frac{(\mathrm{V}-\mathrm{Vo}) \times 0.004157 \times 250 \times 100}{\mathrm{~g} \times 25}
$$

where:

$\mathrm{V} \quad=$ volume of $0.1 \mathrm{~N} \mathrm{KMnO}_{4}$ for sample titration $(\mathrm{mL})$

$\mathrm{Vo}=$ volume of $0.1 \mathrm{~N} \mathrm{KMnO}_{4}$ for blanco sample titration $(\mathrm{ml})$

$0.004157=$ tannin was equivalent in $1 \mathrm{~mL} 0.1 \mathrm{~N} \mathrm{KMnO}_{4}$

$\mathrm{G}=$ sample mass used in the analysis $(\mathrm{g})$

$250=$ volume of volumetric flask $(\mathrm{mL})$

$25=$ volume of Indigo carmine $(\mathrm{mL})$

$100=$ percentage $(\%)$

\section{Nutrition content}

Nutrition content determination in each sample was derived by chemical analysis in a dry matter basis
(DM). The nutrients were ash, crude protein (CP), crude fat (CFat), crude Fiber (CF). The method employed was AOAC (2005). The results were used to compute nutrient content in the basis of $\mathrm{g} / \mathrm{kg} \mathrm{DM}$ or percentage $(\%)$.

\section{Data analysis}

Data were analyzed by general linear model for Completely Randomized Design with configuration of 8 treatments and 3 replicates. Treatment differences was set at $\alpha$ value of $0.05 \%$. Data were analysid using SPSS version 23. Normalization of data was performed using transformation technique.

\section{RESULT AND DISCUSSION}

\section{Total tannins}

Total tannin concentration (Table 1) showed a decline trend for all treatments. The highest reduction $(62 \%)$ was obtained in Fermentated treatment $(0.94 \%)$ compared with control $(2.17 \%)$. A medium decline in tannin concentration (43-53\%) was shown by sundrying $(1.17 \%)$, water boiling $(1.40 \%)$, and water soaking $(2.31 \%)$. Lowest respons $(4-9 \%)$ was detected in Oven-dried (2.23\%), $\mathrm{RenNaOH}(2.31 \%)$, and RenHCl (2.36\%). Total tannin concentration detected in the current experiment fit to the range of $1.3-17.2 \%$ reported by Gemede \& Hassen (2015) in various tropical shrub forages in South Africa.

Table 1. Total tannins of Chromolaena odorata subjected to various pre-treatment methods

\begin{tabular}{lc}
\hline \hline Treatment & Total tannins $(\% \mathrm{DM})^{*}$ \\
\hline Fresh & $2.47^{\mathrm{b}}$ \\
Sun-dried & $1.17^{\mathrm{a}}$ \\
Oven-dried & $2.23^{\mathrm{b}}$ \\
Boiled & $1,40^{\mathrm{a}}$ \\
RenWater & $1.31^{\mathrm{a}}$ \\
RenNaOH & $2.31^{\mathrm{b}}$ \\
RenHCl & $2.36^{\mathrm{b}}$ \\
Fermentated & $0.94^{\mathrm{a}}$ \\
SEM & 0.033 \\
P-value & $<0.001$ \\
\hline
\end{tabular}

*Different supercript in the same column shows significant difference at alfa $5 \%$

Analysis variance showed that there were 4 treatments which significantly reduced tannin concentration by $43-62 \%$ compared with control. The treatments were Fermented, Boiled, RenWater, and 
Sun-dried. Other treatments (Oven-dried, RenNaOH, and $\mathrm{RenHCl}$ ) had no significant effect $(\mathrm{P}>0.05)$ compared with control. These results are in line with Roger et al. (2015) who showed that fermentation reduces total tannin concentration. Conclusive explanation about treatment effects on tannin concentration could not be established in the present experiment since types of tannins were not characterized or have not been published elsewere. However, reduction in tannin concentration in Fermented treatment could be the effect of chemical activities from enzymes produced by various fermentative microbes. These enzymes might damage tannin-enzyme and protein-tannin complex to release protein from tannin in the residual solution (Taylor \& Duodu 2014). Furthermore, there was a possibility of continuing hydrolysis of soluble tannins by microbial enzymes to form other compounds during anaerobic fermentation.

A siginificant decreased in tannin concentration for water-boiled and water-soaked treatments could be related to dissolution of soluble tannin compounds (gallotannin goup) in the water. Unknown tannin composition (types of tannins) in the present study results in unknown proportion of soluble tannins compared with other three groups (ellagitannins, complex tannins dan condensed tannins). Dissolution of tannins in the water in the current study could be possible since most gallotannins have polyol residues derived from D-glucose (Khanbabaee \& van Ree 2001). Khanbabaee \& van Ree (2001) reported that gallotonnins type 2,3,4,6-tetra-O-galloyl-Dglucopyranose and 1,2,3,4,6-penta-O-galloyl- $\beta$ - $D$ glucopyranose are intermediary key compounds which have a crucial role in biosythesis of almost all phenolic compounds in plants. Available water would be a good medium for chemical reactions related to tannin hydrolysis.

Low heat application (sun-dried) also significantly reduced tannin concentration by about 53\% in C. odorata. This is clearly different from medium heat application (oven-dried at $60^{\circ} \mathrm{C}$ ) which showed an insignificant effect (only 9\%) compared with control. Lesser tannin reduction $(3.4 \%$ ) was also reported by Rakić et al. (2004) who oven-drying oak skin at $60^{\circ} \mathrm{C}$ temperature. Djordjevic et al. (1995) proposed that important reactions occur due to heating are hydrolysis, oxidation, polymerization, and interaction of composition and decomposition processes.

Different response of tannins to heat application could be explained by using statement of Hagerman (2002) that tannins reactions is highly affected by temperature. High temperature stimulate condensation reaction of tannins to form complex bond with other compounds. Slow drying at a low temperature, such as in Sun-dried treatment, might allow hydrolysis and decomposition of tannins (Makkar \& Becker 1996). As tannins have hydrophobic bonds, it will form a strong ionic bond at high temperature (Haslam 1989). This might be the explanation to the insignificant reduction in Ovened-dried treatment.

No different in $\mathrm{NaOH}$ or $\mathrm{HCl}$ treatmet with control showed that tannins are less reactive to strong acid or basic solution. Lack of tannin response to strong acid $(2 \mathrm{M} \mathrm{HCl})$ and base $(2 \mathrm{M} \mathrm{NaOH})$ was also reported by Osawa \& Walsh (1993) for tanic acid. This might related to ionization in hydroxyl phenol group in tannins (Hagerman 2002) hence protecting it from hydrolysiss processes.

\section{Nutrition content}

The effects of various treatments on nutrient content of $C$. odorata is shown in Table 2. There are three essential nutrient variables determining biological value of $C$. odonata which were affected by treatment i.e organic matter, crude protein, and crude fiber. Data in Table 2 shows that the highest organic matter was obtained in RenHCl treatment $(922 \mathrm{~g} / \mathrm{kg} \mathrm{DM})$ and the lowest one was in Fermented treatment (879 g/kg DM). Organic matter usually has high hydrogen thus increase opportunity for tannins to bind to other organic materials such as cellulose and hemicellulose (McSweeney et al. 2001). Theoritically, soaking of feed materials in acid solution, such as $\mathrm{HCl}$, could cause hydrolysis of complex chemical bonds in organic compunds including tannin-protein or tannin-other organic materials. However, acid or basic affect in the present study was very low compared with other treatments. Data in Table 1 showed that $\mathrm{HCl}$ ability to reduce tannins in $C$. odorata was much lower than Fermented treatment. This possibly related to mode of hydrolysis between the two treatments. For RenHcl treatment, the only mode of hydrolysis was by acid effect since most of fermentative microbes might have died in strong acid solution. In contrast, hydrolysis processes in Fermented treatment is mostly done by a variety of fermentative microbes. Released organic matter in $\mathrm{HCl}$ treatment might not undergo further decomposition. In the Fremented treatment, even though it has a high ability to reduce tannins causing high amount of organic matter released from the complex, this organic matter might undergo further hydrolysis by microbe during fermentation hence reduces its proportion in the residu. In such a condition, addition of soluble carbohydrates (SCs) is trongly recommended. The SCs are important in fermentation processes as it will improve nutrient value and reduce 
Table 2. Nutrient content of $C$. odorata due to treatments

\begin{tabular}{|c|c|c|c|c|c|c|}
\hline \multirow{2}{*}{ Treatment } & \multicolumn{6}{|c|}{ Nutrient content } \\
\hline & Dry material & Organic material & Crude protein & Crude Fat & Crude Fiber & BETN \\
\hline & \multicolumn{6}{|c|}{ 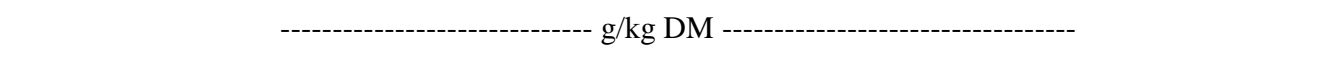 } \\
\hline Fresh & $266^{\mathrm{b}}$ & $908^{c}$ & $174^{\mathrm{f}}$ & $30^{\mathrm{e}}$ & $127^{\mathrm{c}}$ & $578^{\mathrm{a}}$ \\
\hline Sun-dried & $839^{\mathrm{a}}$ & $866^{\mathrm{f}}$ & $258^{\mathrm{b}}$ & $48^{\mathrm{d}}$ & $108^{\mathrm{b}}$ & $452^{\mathrm{d}}$ \\
\hline Oven-dried & $863^{\mathrm{a}}$ & $888^{\mathrm{d}}$ & $250^{\mathrm{c}}$ & $67^{\mathrm{c}}$ & $99^{\mathrm{b}}$ & $471^{\mathrm{bc}}$ \\
\hline Boiled & $245^{\mathrm{b}}$ & $914^{\mathrm{b}}$ & $196^{\mathrm{e}}$ & $106^{\mathrm{a}}$ & $135^{c}$ & $477^{\mathrm{b}}$ \\
\hline RenWater & $271^{\mathrm{b}}$ & $914^{\mathrm{b}}$ & $228^{c}$ & $109^{\mathrm{a}}$ & $145^{\mathrm{d}}$ & $433^{\mathrm{e}}$ \\
\hline $\mathrm{RenNaOH}$ & $247^{\mathrm{b}}$ & $867^{\mathrm{f}}$ & $199^{\mathrm{de}}$ & $62^{\mathrm{c}}$ & $130^{c}$ & $474^{\mathrm{b}}$ \\
\hline RenHCl & $183^{c}$ & $922^{\mathrm{a}}$ & $202^{\mathrm{d}}$ & $107^{a}$ & $151^{\mathrm{d}}$ & $462^{c d}$ \\
\hline Fermented & $243^{\mathrm{b}}$ & $879^{e}$ & $290^{\mathrm{a}}$ & $75^{\mathrm{b}}$ & $86^{\mathrm{a}}$ & $429^{\mathrm{e}}$ \\
\hline SEM & 0.002 & 0.002 & 0.012 & 0.006 & 0.006 & 0.002 \\
\hline P-value & $<0.001$ & $<0.001$ & $<0.001$ & $<0.001$ & $<0.001$ & $<0.001$ \\
\hline
\end{tabular}

*Different supercrpit in the same column showssignificant different at alfa value of $5 \%$

dry material losses (McDonald et al. 1991). The strategy is very crucial in silage making particularly for feedstuff with low $\mathrm{C}: \mathrm{N}$ ratio.

The highest crude protein content $(290 \mathrm{~g} / \mathrm{kg} \mathrm{DM})$ was shown in Fermented treament and the lowest (174 $\mathrm{g} / \mathrm{kg} \mathrm{DM}$ ) was in control (Fresh). Data in Table 2 shows that all treatments increased protein content above control. This might be explained by data in Table 1 that all treatments were able to decrease tannin concentration hence an increase in tannin free proteins. Fermentation increase crude protein of $C$. odorata due to its capability disrupt tannin-protein complex. Besides, chemical activity of fermentative microbes and lysis of tennin-enzyme and tannin-protein complexes (Taylor \& Duodu 2014). It is presumed that an increase in protein content in the Fermented treatment is likely due to contribution of microbial proteins synthesized during fermentation process. Crude protein content in water-boiled treatment (196 g/kg DM) was higher than control but lower than other treatments. This possibly related to dissolution of tannin-protein complex. Heat from boiling likely to cause denaturation of protein hence releases proteins from protein-tannin linkage in C. odorata.

Lowest crude fiber (86 $\mathrm{g} / \mathrm{kg} \mathrm{DM}$ ) was found in fermented treatment and the highest $(145 \mathrm{~g} / \mathrm{kg} \mathrm{DM})$ content was in RenWater treatment. A decline of crude fibre in Fermented ttreatment likely to be caused by fiber-digested bacterial activities during fermentation. Among cellulotic species, there are fiber digested bacteria to diegst cellulose, hemicellulose, and starch (Kana Hau et al. 1005). Water soaking (RenWater) had a very poor capability to reduce crude fiber content. Fiber consists of cellulose, hemicellulose, and lignine.
Usualy, cellulose and hemicellulose would be degraded with the help of cellulose and hemicellulose enzymes, whereas water has no direct effect on crude fiber degradtion.

Crude fat of fresh C. odorata was $30 \mathrm{~g} / \mathrm{kg} \mathrm{DM}$ and tended to increase after treatment. Highest fat content detected in RenWater treatment (109 g/kg DM). This increase might be caused by a significant loss in non-fat compounds, particularly carhohydrates due to fermentation and other processes. Reduction in non-fat organic compounds will automatically increase proportion of crude fat in feed materials.

BETN consist of highly digestible carbohydrate compounds. BETN content of fresh $C$. odorata was 578 $\mathrm{g} / \mathrm{kg}$ DM. Lowest BETN content (429 g/kg DM) was in the Fermented treatment. BETN content in fresh $C$. odorata was very high since all soluble carbohydrates have not been degraded, whereas in the Fermented treatment, soluble carbohydrates have been degraded by microbes during the fermentation processes. Provision of additives such as soluble carbohydrate is highly recommended in fermentation (McDonald et al. 1991).

\section{CONCLUSION}

Fermentation was the most effective technique to reduce tannin concentration yet improves nutrient value of $C$. odorata. Fermentation decreased total tannin concentration by $62 \%$, reduced crude fiber from 127 $\mathrm{g} / \mathrm{kg} \mathrm{DM}$ into $86 \mathrm{~g} / \mathrm{kg} \mathrm{DM}$ (32\% improvement), and increased crude protein from content from $175 \mathrm{~g} / \mathrm{kg} \mathrm{DM}$ to $290 \mathrm{~g} / \mathrm{kg} \mathrm{DM}$ (60\% improvement). This study showed that anaerobic fermentation is the best method 
to treat $C$. odorata to improve its biological value as a potential animal feed.

\section{REFERENCES}

Akinmoladun AC, Obuotor EM, Farombi EO. 2010. Evaluation of antioxidant and free radical scavenging capacities of some Nigerian indigenous medicinal plants. J Med Food. 13:444-451.

[AOAC] Association of Official Analytical Chemist. 2005 Official Methods of Analysis of AOAC International. Available from: http://www.eoma.aoac.org/

Atanassova M, Christova-Bagdassarian V. 2009. Determination of tannins content by titrimetric method for comparison of different plant species. J Univ Chem Technol Metall. 44:413-415.

Bhatta R, Uyeno Y, Tajima K, Takenaka a, Yabumoto Y, Nonaka I, Enishi O, Kurihara M. 2009. Difference in the nature of tannins on in vitro ruminal methane and volatile fatty acid production and on methanogenic archaea and protozoal populations. J Dairy Sci. 92:5512-5522. doi: 10.3168/jds.2008-1441.

Bira GA, Mullik ML, Jelantik IGN, Maranatha G, Mullik YM, Sudarma IMA, Dahlanuddin. 2015. Incremental levels of C. odorata in complete diet does not impar intake, rumen fermentation and microbial crude protein synthesis in cattle. In: Proceeding 3rd International Seminar Animal Industry. [Bogor (Indones)]: Bogor Agricultural University. p. 229-232.

Djordjevic S, Pace CP, Stankovich MT, Kim JJ. 1995. Threedimensional structure of butyryl-CoA dehydrogenase from Megasphaera elsdenii. Biochemistry. 34:21632171.

Gemede BS, Hassen A. 2015. Effect of tannin and species variation on in vitro digestibility, gas, and methane production of tropical browse plants. Asian-Australasian J Anim Sci. 28:188-199.

Gemede BS, Hassen A. 2015. Effects of tannin and species variation on in vitro digestibility, gas and methane production of tropical browse plants. AJAS. 28:188 199.

Hagerman AE. 1992. Tannin-protein interaction. In: Chi-Tang $\mathrm{H}$, Chang YL, Mou-Tuan H, editors. Phenolic Compd food their Eff Heal I. Washington DC (USA): American Chemical Society. p. 237-247.

Hagerman AE. 2002. Tannins chemistry. Tannin Handbook. Oxford (USA): Miami University.

Hai P V, Everts H, Tien D V, Schonewille JT, Hendriks WH. 2012. Feeding Chromonaela odorata during pregnancy to goat dams affects acceptance of this feedstuff by their offspring. Apllied Anim Behav Sci. 137:30-35.

Haslam E. 1989. Chemistry and significance of condensed tannins. In: Hemingway RW, Karchesy JJ, editors. Plant polyphenols. Cambridge (UK): Cambridge University Press.
Hue KT, Van DTT, Ledin I, Spörndly E, Wredle E. 2010. Effect of feeding fresh, wilted and sun-dried foliage from cassava (Manihot esculenta Crantz) on the performance of lambs and their intake of hydrogen cyanide. Livest Sci. 131:155-161.

Kana Hau D, Nenobais M, Nulik J, Katipana NGF. 2005. Pengaruh probiotik terhadap kemampuan cerna mikroba rumen sapi Bali. In: Prosiding Seminar Nasional Teknologi Peternakan dan Veteriner. Bogor (Indones): Pusat Penelitian dan Pengembangan Peternakan. p. 171180.

Khanbabaee K, van Ree T. 2001. Tannins: Classification and definition. Nat Prod Rep. 18:641-649.

Makkar HPS. 2003. Quantification of tannins in three and shrub foliage. A laboratory manual. Dordrech (Nethrelands): Kluwer Academic Publisher.

Makkar HPS, Becker K. 1996. Effect of pH, temperature, and time on inactivation of tannins and possible implications in detannification studies. J Agric Food Chem. 44:12911295.

McDonald P, Henderson AR, Heron SJE. 1991. The biochemistry of silage. 2nd ed. Marlow (USA): Chalcombe Publication.

McSweeney CS, Palmer B, Mcneil DM, Krause DO. 2001. Microbial interactions with tannins: Nutritional consequences for ruminants. Anim Feed Sci Technol. 91:83-93.

Mullik ML. 2002. Laporan penelitian: Strategi pemanfaatan semak bunga putih (Chromolaena odorata) untuk meningkatkan produksi ternak dan pendapatan peternak di daerah lahan kering.

Mullik ML, Jelantik IGN, Mulik YM, Dahlanuddin, Wirawan IGKO, Permana B. 2014. Pemanfaatan semak bunga putih (Chromolaena odorata) sebagai pakan lokal sumber protein untuk ternak sapi: konsumsi, daya cerna dan fermentasi rumen. In: Prosiding Seminar Nasional III HITPI. Bukit Tinggi (Indones).

Onkaramurthy M, Veerapur VP, Thippeswamy BS, Madhusudana Reddy TN, Rayappa H, Badami S. 2013. Anti-diabetic and anti-cataract effects of Chromolaena odorata Linn in streptozotocin-induced diabetic rats. J Ethnopharmacol. 145:363-372.

Osawa R, Walsh TP. 1993. Effects of acidic and alkaline treatments on tannic acid and its binding property to protein. J Agric Food Chem. 41:704-707.

Patra AK, Saxena J. 2011. Exploitation of dietary tannins to improve rumen metabolism and ruminant nutrition. $\mathbf{J}$ Sci Food Agric. 91:24-37.

Rakić S, Maletić R, Perunović M, Svrzić G. 2004. Influence of thermal treatment on tannin content and antioxidation effect of oak acorn quercus cerris extract. J Agric Sci. 49:97-107. 
Mullik et al. Anaerobic fermentation effectively reduces concentration of total tannins in Chromolaena odorata

Roger T, Léopold TN, Funtong MC. 2015. Nutritional properties and antinutritional factors of corn paste (kutukutu) fermented by different strains of lactic acid bacteria. Int J Food Sci.:1-13.

Taylor JRN, Duodu KG. 2014. Effects of processing sorghum and millets on their phenolic phytochemicals and the implications of this to the health-enhancing properties of sorghum and millet food and beverage products.
Wina E. 2010. Utilization of tannin containing shrub legumes for small ruminant production in Indonesia. Wartazoa. 20:21-30.

Wina E, Tangendjaja B, Palmer B. 2000. The effect of drying condition on Condensed Tannin Estimater (CT) in Calliandra calothyrsus. In Brooker: Tannins in Livestock and Human Nutrition. ACIAR Proceeding. 92:106-110. 